\title{
Digital transformation by enabling strategic capabilities in the context of "BRICS"
}

\author{
Cristiana Rennó D’Oliveira Andrade and Cláudio Reis Gonçalo \\ Postgraduate Program in Administration (PPGA), \\ University of the Itajai Valley (UNIVALI), Biguaçu, Brazil
}

\section{The context of BRICS}

Received 31 December 2020 Revised 7 May 2021 Accepted 16 May 2021

\begin{abstract}
Purpose - This study characterizes the scenario of emerging countries (ECs) - "Brazil, Russia, India, China and South Africa (BRICS)" concerning digital transformation and its association with the Industry 4.0 (I4.0) value creation system. For such, the authors developed a discussion paper based on content analysis of 857 journals in business administration, describing in a proposed framework the institutionalization "BRICS" policies that nurture global competitiveness among ECs and development needs to catching up.

Design/methodology/approach - Data from 16 official documents of government, ministries and economic studies were analyzed by applying Atlas TI contrasting theory of 875 papers to develop and discuss the framework. Content analysis showed research gaps, technological needs and governance to enable firms to sustain competitive advantages applying I4.0 value creation system. Results converged into a microfoundation of the agile journey of a digital transformation to global organizations in between BRICS.

Findings - This paper's central question is to understand: How can organizations achieve a sustainable I4.0 value creation system adopting digital transformation in "BRICS"? The reduced transaction costs driven by platforms and ecosystems orchestration and the related or integrated multiple level sources of knowledge could speed benefits of domestic firms and subsidiaries of global organizations. Research gaps could be understood by a new combination of resources and knowledge, exploiting technologies and, also, the discussion of social economic relevance of I4.0.

Research limitations/implications - Because of the complexity and the novelty of the framework, further studies could be discussed by its elements. New structures and paths for alternative strategic factors may be proposed in the future with the inclusion of new relationships in the adoption of platform business models and ecosystems. Future studies should consider digital knowledge-based assets attained to economic activities across national boundaries; data analytics or data-driven technology adoption and their effects on global attractiveness.

Practical implications - The paper implicates in evaluating whether dynamic capabilities subsidize performance propitiating the catching up with a focus on the I4.0 system and digital transformation management journey. The proposed framework demonstrates the benefits of digital transformation by enabling strategic capabilities, making efforts to reduce a lack of research paths concerning the policy attributes that define the platform use strategy from an architectural standpoint and its benefits.

Social implications - The particularities of turning either an I4.0 global organization or a digital organization operate in various environments, allowing access to the activities' digital context. Social implications concerning digital resources as strategic accelerators are determined by the BRICS peculiarities, such as social behavior, consumerism or communication pattern, leadership and workforce skills. Finally, political aspects and interference in the economy are deployed in society what must be considered.

Originality/value - This paper proposes a conceptual framework to better understand whether the heterogeneity of resources could explain I4.0 and digital configurations, while new platforms have driven features in global industrial environments and ecosystems. The seizing opportunities in these countries and
\end{abstract}

(c) Cristiana Rennó D’Oliveira Andrade and Cláudio Reis Gonçalo. Published in Revista de Gestão. Published by Emerald Publishing Limited. This article is published under the Creative Commons Attribution (CCBY 4.0) licence. Anyone may reproduce, distribute, translate and create derivative works of this article (for both commercial and non-commercial purposes), subject to full attribution to the original publication and authors. The full terms of this licence may be seen at http://creativecommons. org/licences/by/4.0/legalcode

This work was developed with the support of the CAPES (Brazilian Coordination for the Improvement of Higher Education Personnel) through the support program for the Graduate Studies of Community Education Institutions (PROSUC), according to 149/2017 CAPES Ordinance.

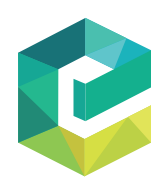

Revista de Gestão Vol. 28 No. 4,2021 pp. $297-315$

Emerald Publishing Limited e-ISSN: $2177-8736$ p-ISSN: $1809-2276$ DOI 10.1108/REGE-12-2020-0154 
REGE 28,4 sense-making use of platforms and orchestration of ecosystems are found as the critical topics being the main value of this important discussion.

Keywords Digital transformation, 4.0 industry, Strategic capabilities, Emerging countries

Paper type Conceptual paper

\section{Introduction}

This study aims to understand how firms can build and reconfigure internal and external digital competencies supported by the opportunities of adopting the Industry 4.0 (I4.0) technologies, as soon as this transition takes place all over the world (OECD, 2019). The conceptual evolution of applying the I4.0 technologies is analyzed in the emerging countries (ECs) by the sociotechnical and economic perspectives (Erro-Garcés, 2019). As result, a framework is proposed to organizations review their journey toward I4.0 and convergent digital transformation.

The Fourth Industrial Revolution requires understanding a new economic scenario in which globalization and digitalization will be necessary "faces of the same coin" in the new strategic game. Insofar as the digital world merges continuously, this fast change involves the development of unique capabilities. These will be performed by enabling strategic processes such as big data collections (Gandomi and Haider, 2015), intelligent analytical practices (Chen, Chiang, \& Storey, 2012) and new business models (Schallmo, Williams, \& Boardman, 2017). In this sense, public policies, data-driven actions and strategic decisions request organizational answers toward the global digital environment (Silva, Bernardes, Ramalho, Ekel, Martins, \& Libório, 2019; Erro-Garcés, 2019).

Analyzing the ECs - BRICS (Brazil, Russia, India, China and South Africa), the structural discussion may be developed at the global level throughout economic crises and geopolitical reconfigurations. Due to the shift of innovation locus to a global intensity (Teece, 2007), some of the core organizational axioms had been being fundamentally challenged to gain performance (Teece, 2018). Regarding digital resources as strategic accelerators, key discussions are determined by BRICS with the peculiarities on each country, such as social behavior, consumerism or communication patterns (Jacobides, Sundararajan, \& Van Alstyne, 2019).

The global economy is operating under contrasting rules, and global firms are challenging on a new strategic field, winning or losing competitive advantage, based on efficiency and innovation (Petricevic and Teece, 2019). As far as the value creation by companies 4.0 has been applied (Ghobakhloo, 2018), managerial competencies have been required by supporting digital readiness and transformation among the BRICS countries. Those build the heterogeneities of global enterprises meanwhile the recombination and reconfiguration of assets are required by the 4.0 Industry Journey.

Moreover, the political uncertainty (Teece, 2020), the restricted resource balance (Vanacker, Collewaert, \& Zahra, 2017) and the volatile sociopolitical conditions (Zhang, $\mathrm{Wu}, \&$ Chen, 2018) are firm performance pitfalls (George, 2005). These require, among BRICS, business reconfiguration once the alliance contains the largest middle-income economies.

We propose a framework to demonstrate the benefits of digital transformation by enabling dynamic capabilities, making efforts to reduce a lack of research paths concerning the policy attributes that define platform use for strategical configuration from an architectural standpoint and its benefits (Kazan, Tan, Lim, Sørensen, \& Damsgaard, 2018). We are aware that there is much to learn about the role of dynamic capabilities regarding platforms more generally (Teece, 2017) or the reason why multinational organizations may reconfigure their resources aiming to develop industrial connections. All those strategies try to obtain marketing benefits of "digitization" and "servitization" in their ideological and technological foundations (Cenamor, Sjödin, \& Parida, 2017; Hollebeek, 2019). 
In sum, we want to analyze whether the heterogeneity of resources could explain such configurations, while new platforms have driven features in industrial environments that could either consider digital ecosystems (Helfat and Peteraf, 2009). As dynamic capabilities are the company's ability to integrate, build and reconfigure its internal and external competencies for strategic performance (Teece, 2009), the main contribution is to evaluate whether dynamic capabilities subsidize performance propitiating the catching up with a focus on the I4.0 system and digital transformation management journey.

\section{BRICS in the context of 4.0 Global Competitiveness Index}

Emerging economies with growing innovation capacity, such as China, India and Brazil, should also make a better balance between technology integration and human capital investments (Schwab, 2016). This alliance aims to convert their growing economic power into greater geopolitical influence. This acronym was built due to similarities among those countries considering emerging gross domestic product (GPD) growth and purchasing power parity; economic partnership and cooperation into education or international governance attained their national interests.

Concerning BRICS 4.0 Competitiveness Index analysis, Figure 1 expresses the overall performance. China leads the ranking (28th), Brazil (7th) and India (68th) had been improving some social-economic issues. Russia (43rd) and South Africa (60th) have gained importance in innovation performance. Furthermore, some countries, despite the turbulence in the industries, and their poor governance (institutionally weak and risky countries) tend to receive significant FDI (Foreign Direct Investment) flows. That is an opportunity for economic growth and catching up.

Brazilian efforts are ranked worst in most of the pillars and performance indicators. Results suggest that there should be a better balance between technology investments and human capital capacitation regarding digital skills. However, according to the Brazilian government, policies are driven to simplify regulations to start and close a business, efforts in the improvement of high innovation capability level (40th) and finally greater trade openness.

This fact is critical once it could cause insufficient endowment that may increase the risk of unemployment and negative social consequences despite Brazil's most improved economy in Latin America. Like the other BRICS countries, there is a massive gap in talent adaptability making human capital investments, one of the most critical factors of productivity in the coming decade. Industries such as automotive and agribusiness could be benefited from other funds (Innovations' Goodness' Law) and regulation as the artificial intelligence (AI) and Internet of things (IoT) laws take place.

Then, due to Brazilian economic and social restrictions that affect performance, there are efforts to improve infrastructure and access to information and communication technologies; research, development and innovation; adequation of the regulatory environment; promotion of information and communication technology (ICT) adoption and finally development of educational skills. Investments in technological infrastructure and the professionals' qualifications have continuously improved the legal framework and the instruments to encourage innovation.

The Russian strategies, like the Brazilian initiative, have already begun implementing changes to adapt to this new reality, with Putin (2019) to create the right technological management conditions by 2035 (WEF \& Schawb, 2019). The Russian system's capabilities include data and financial analysis, insurance and logistic services, as well as electronic digital signature (Table 1).

The Russian Ministry of Communications and Mass Media became the responsible ministry concerning the digital economy and AI to achieve a new level of effectiveness. So, sectorial roadmaps define intermediate steps on the way to 2035, research and development (R\&D) and 
REGE

28,4

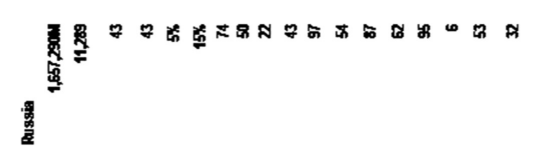

300

Figure 1.

BRICS competitiveness indexes

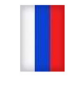

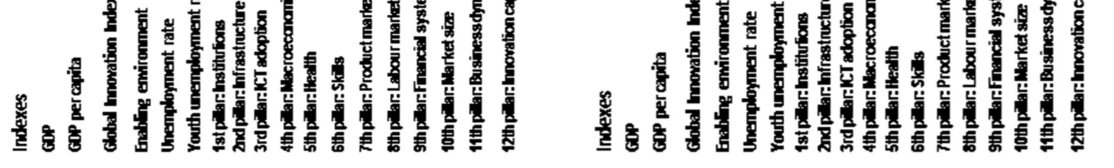

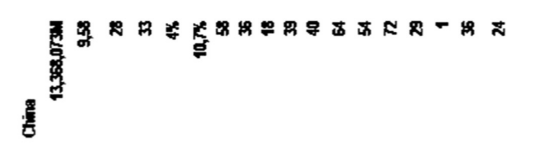

0
0
0
0
0
0
0
0
0
0
0
0
0
0
0
0
0
0

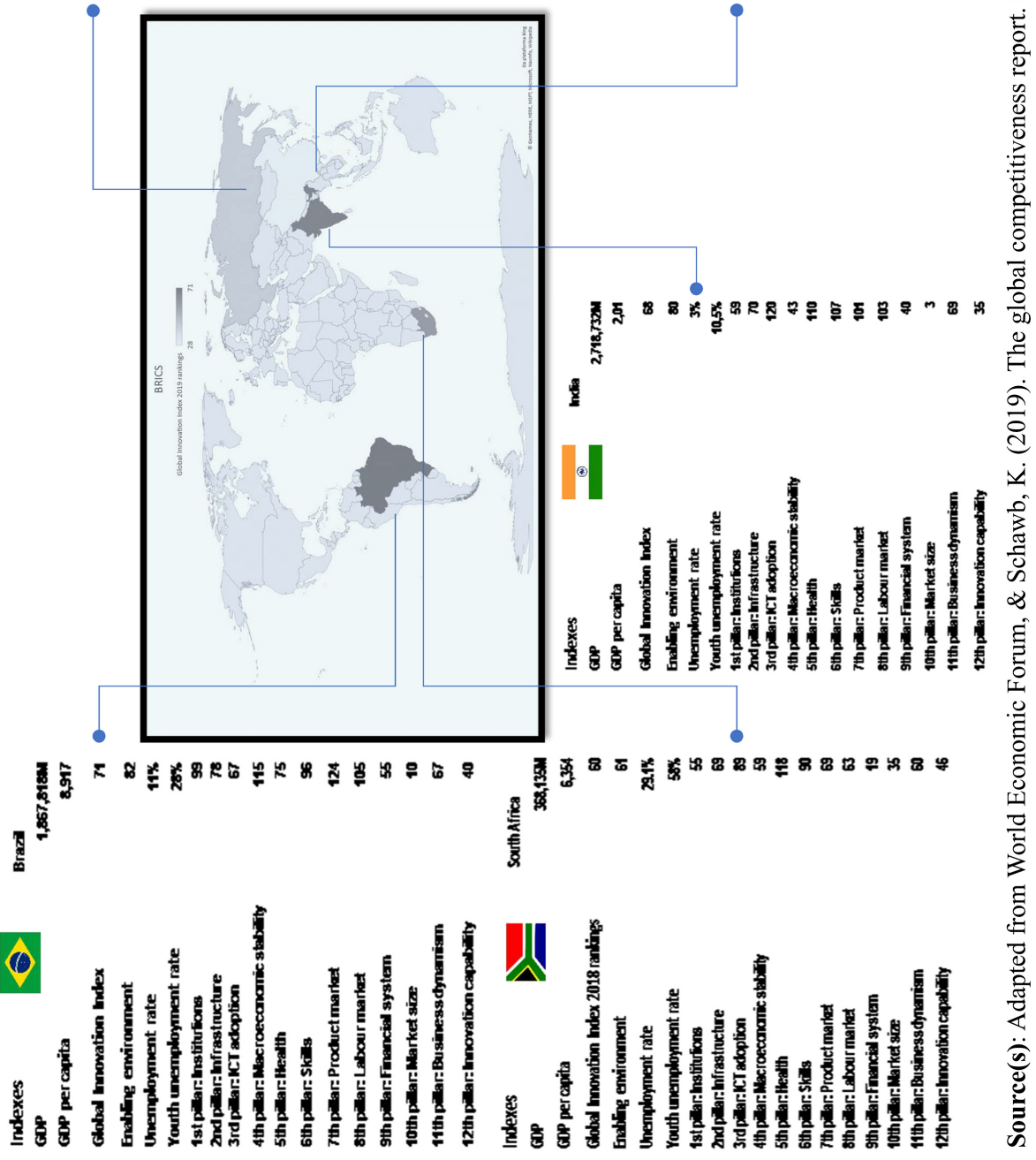




\begin{tabular}{|c|c|c|c|c|c|c|}
\hline BRICS I4.0 indexes & Brazil & Russian Federation & India & China & South Africa & The context of \\
\hline Global Competitiveness Index 4.0 & 71 & 43 & 68 & 28 & 60 & \\
\hline Property rights & 91 & 56 & 87 & 43 & 67 & \\
\hline Intellectual property protection & 95 & 90 & 57 & 53 & 46 & \\
\hline Current workforce & 110 & 47 & 105 & 77 & 72 & \\
\hline Mean years of schooling & 101 & 48 & 117 & 95 & 60 & \\
\hline Skills of the current workforce & 131 & 49 & 64 & 37 & 101 & 301 \\
\hline The extent of staff training & 84 & 74 & 50 & 38 & 40 & \\
\hline Skillset of graduates & 131 & 77 & 93 & 35 & 102 & \\
\hline The skillset of university graduates & 126 & 86 & 115 & 57 & 93 & \\
\hline Digital skills among the active population & 133 & 27 & 59 & 45 & 126 & \\
\hline Ease of finding skilled employees & 129 & 47 & 71 & 41 & 98 & \\
\hline Future workforce & 76 & 55 & 108 & 61 & 99 & \\
\hline Skills of the future workforce & 92 & 63 & 114 & 38 & 107 & \\
\hline Innovation ecosystem & 44 & 34 & 40 & 27 & 50 & \\
\hline 11th pillar: Business dynamism & 67 & 53 & 69 & 36 & 60 & \\
\hline Entrepreneurial culture & 56 & 77 & 41 & 34 & 39 & \\
\hline Attitudes toward entrepreneurial risk & 63 & 59 & 43 & 31 & 46 & \\
\hline Growth of innovative companies & 60 & 96 & 33 & 42 & 44 & \\
\hline Companies embracing disruptive ideas & 56 & 71 & 33 & 25 & 36 & \\
\hline 12th pillar: Innovation capability & 40 & 32 & 35 & 24 & 46 & \\
\hline State of cluster development & 58 & 101 & 38 & 26 & 35 & \\
\hline International coinventions & 67 & 54 & 59 & 50 & 65 & \\
\hline Multistakeholder collaboration & 74 & 48 & 36 & 30 & 39 & \\
\hline Collaboration within a company & 78 & 42 & 39 & 41 & 44 & \\
\hline Collaboration between companies & 74 & 56 & 26 & 17 & 53 & \\
\hline University-industry collaboration in R\&D & 77 & 51 & 46 & 30 & 31 & \\
\hline Research and development & 29 & 23 & 26 & 10 & 44 & \\
\hline Scientific publications & 24 & 22 & 21 & 13 & 33 & \\
\hline Patent applications & 58 & 48 & 63 & 32 & 51 & \\
\hline R\&D expenditures & 27 & 34 & 52 & 15 & 45 & BRICS DT 4.0 \\
\hline Research institutions prominence & 14 & 9 & 8 & 2 & 41 & competitiveness \\
\hline Source: The authors (2020) & & & & & & indexes \\
\hline
\end{tabular}

innovation project calls. In addition, as reinforced by Veretekhina et al. (2018), Russian companies, universities and this nation's scientific bodies are claimed to join those initiatives.

Data analytics is critical for workforce skills development (Geroge \& Lin, 2017). It could be perceived with the second-best rank at BRICS considering infrastructure, ICT adoption and business dynamism. Governance is ranked best in Russia's pillar and its relations to shareholders. However, China (the best in shareholder governance) and South Africa are more aggressive. Concerning digital skills and the labor market that should absorb them, Russia presents the best scores at the rank in between BRICS but is the worst place in the growth of innovative companies and companies that adopt disruptive ideas. India has the lowest R\&D investment power, ranking 52nd in this global ranking.

Although most of the rankings are favorable, there is a Chinese development gap toward the legal framework's adaptability to digital business models. That is the worst position within BRICS. Also, firms operating in China should be cautious in their use of business and political ties and adapt their tie utilization to changing institutional and market environments as official political control, both internally and in terms of foreign policy occur (Sheng, Zhou, \& Li, 2011).

As emerging market enterprises had become common in today's business world, there should be great efforts to promote the catching up once emerging market governments are economically imperative and institutionally complementary to offsetting competitive disadvantages of emerging market enterprises in global competition (Luo, Xue, \& Han, 
REGE 28,4

\section{2}

2010). The most well-succeed countries at BRICS, China, is trying to enhance digital companies such as Baidu, Alibaba and Tencen, having the major capital market for AI startups and publishes the most research papers on innovation as shown in Appendix 1.

The South African context is directly associated with the creation of ICT ecosystems and the development of innovative ICT capabilities. This country presents a high unemployment rate and is still facing other social barriers that may be surpassed. The breadth of external technology access seems to be more relevant and more important than the depth of technology exploitation in China (Li-Ying and Wang, 2015).

South African companies try to develop technologies and systems, business models and corporate structures, as well as sunk investments regardless of their outdated infrastructure (see in Figure 1 and Table 2). Workforces may not be ready for the digital revolution that is already underway across the globe. Those barriers are obstructing South Africa's ability to integrate new technologies into the economy.

BRICS digital

transformation (DT)

policies

DT_4.0 pillar

Most affected sectors of DT

Brazil: Brazilian digital transformation strategy

Russia: Information society development strategy (2017-2030) India: Digital India

China: Made in China 2025
Digital citizenship, expansion of access and use ICT, research, development and innovation (RD\&I) Digital environment confidence, education and training, dimension International, economy

digitalization

Digital foundations for the public sector, private sector and citizens or consumers

Broadband highways, universal access to mobile connectivity, public internet access program, egovernance: Reforming government through technology, e-Kranti electronic delivery of services, information for all, electronics manufacturing, IT for jobs and early harvest programs

Innovation (R\&D and patents), manufacturing quality effectiveness, digital research tools and digitization of key production and work processes, green manufacturing, optimization and qualification of the workforce in priority sectors

Digital transformation of the public service, digital access and digital inclusion
Telecommunications and ICT sectors; public sector; RD\&I; education; automotive and auto parts; services; cybersecurity; energy; healthy; transport and computer science

Public sector; telecommunications and ICT sectors; education; RD\&I; services; bank and financial services; agriculture Network and cloud infrastructure sectors; public sector; electronic sector; information technology/information technology enabled services (IT/ITES) sectors and telecommunication services

Advanced marine equipment and hightech vessels; advanced rail and equipment; agricultural machinery and technology; aviation and aerospace equipment; biopharmaceuticals and high-end medical equipment; integrated circuits and new generation information technology; power equipment and technology; high-end manufacturing control machinery and robotics and low and new-energy vehicles and new materials

South Africa: IT

Table 2.

transformation program

BRICS DT_4.0 official policies content analysis

Source: The authors (2020)
Public sector; ICT products and services; e-commerce; education; cybersecurity and safety; telecommunication and health sectors 
Last World Economic Forum (WEF \& Schawb, 2019) had shown it had been establishing policies involving digital technologies, such as analytics, blockchain, virtual reality and AI, which impact South Africa's sectors and sustainability.

On the other hand, those structural reforms should develop the economy and offer better opportunities to entrepreneurship and innovation hubs even though it is among the top countries in Africa for market size.

Official member since 2010, the country has been considered Africa's largest economy even though its economy falls far short of its new partners. The data compiled show the increasing number of innovative companies in which India is the best, although it ranks low in patents. Regarding the implementation of research and development projects, the number of scientific publications and research institutions highlighting the economic data reveals that South Africa shows the worst performance in the ranking (WEF \& Schawb, 2019).

Table 2 expresses the main long-term paths and challenges of the central BRICS policies toward digital transformation. As the BRICS acronym emerged in the international financial sector, new markets are not from the union of countries with cultural and dynamic similarities.

Digital transformation at BRICS is understood as a phenomenon that contains customerdriven strategic business evolution. Such a phenomenon involves the implementation of digital technologies and governance and, also, organizational change toward a better experience by platforms and ecosystems.

Even though within BRICS, there are different firms 4.0 maturity levels among their industries, the majority of enabling technologies are present. Finally, it is essential to highlight that the telecommunication, ICT, education and public sector are an integral part of the digital strategy at BRICS. China, India and Brazil require strengthening their skills and labor market to minimize the risks of negative social spillovers.

\section{Conceptual development of the I4.0 emerging countries' digital transformation strategy (I4.0 ECDTS) framework}

Growth opportunities via digital transformation of leading global companies adopt mechanisms to achieve better international performance and a smart manufacturing/ service system (Ghobakhloo, 2018). Specific mechanisms of relationship (such as platforms and ecosystems) compromise stand out, allowing them to take advantage of the configuration and formation of networks, which leads to marketing benefits of digitization and servitization (Cenamor, Sjödin, \& Parida, 2017).

The first type of such mechanism is related to digital platforms, which play a central role in many firms' value propositions by enabling information management and marketing benefits (Caputo, Garcia-Perez, Cillo, \& Giacosa, 2017; Hollebeek, 2019). Consequently, big data, artificial intelligence and machine learning support I4.0 firms to become priorities by competing in digital platform ecosystems (Subramaniam, Iyer, \& Venkatraman, 2019).

The second type is concerned with ecosystems that explore and exploit opportunities, such as the driven by cocreation capabilities and shared development costs (Kapoor and Argawaal, 2017; Blaschke, Riss, Haki, \& Aier, 2019). This specialized experience can build potential capabilities improving innovation and moving organizational motivation to pursue other new technologies (Eggers \& Park, 2018).

However, there are several types of ecosystems related mainly to value capture, while the innovation ecosystem is related to value creation (De Vasconcelos Gomes, Facin, \& Ikenami, 2018). Those ecosystem approaches describe the increasing interdependence and coevolution of contemporary business and innovation outputs (Aarikka-Stenroos \& Ritala, 2017).

The World Economic Forum (WEF \& Schawb, 2019) highlighting the collaboration by ecosystems is managed with data reliability. The vectors could help to deploy actions toward digitization. Those vectors are illustrated in Figure 2, offering a better understanding 
REGE

28,4

304

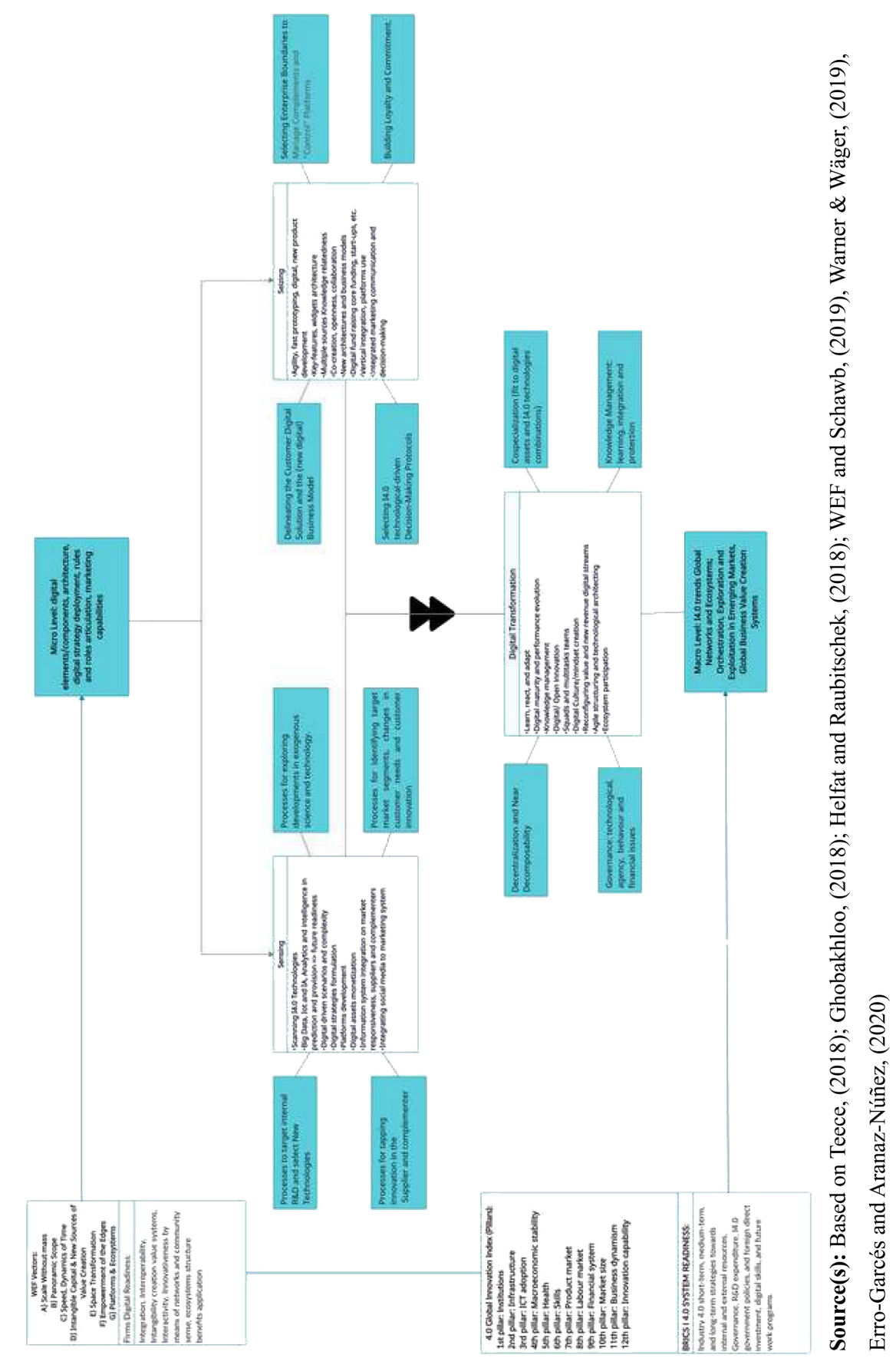

Figure 2.

The I4.0 emerging countries' digital transformation strategy (I4.0 ECDTS) framework 
of the BRICS policies within and across the digital economy and society. The economic vectors are to provide a strategic framework. Experts characterize digital transformation by some characteristics: customer orientation, mobility, speed and guidance on data (Akatkin, Konyavskiy, \& Yasinovskaya, 2017) that are presented at the microfoundation level attributing agility factors (Teece, 2018).

Moreover, Erro-Garcés (2019) analyzed papers concerning the readiness of industrial enterprises and the economies. The majority agreed on the importance of assessing this readiness as it affects the challenges in internal and external factors (Lima \& Araújo, 2019). Two types of factors could be identified as microconditions (strategy of an multinational enterprises (MNE), intraorganizational communication, technologies implemented, employees, products/services and innovation) and macroconditions (the collaboration of institutions and the technological level of the country).

Capabilities only qualify as dynamic if they aim to promote seemingly large amounts of change in a short period, as assumed by Helfat \& Winter (2011), and those changes could presume to adopt platforms or joining ecosystems. Fundamentally, the relation between dynamic and operational capabilities affects strategies either to bear digital or turn digital in ECs to perform globally.

Dynamic capabilities are required for fostering the organizational agility toward sensing and seizing to address deep uncertainty, such as that generated by innovation and the associated dynamic competition toward digital transformation (Teece, Peteraf \& Leih, 2016; Teece, 2018). The understanding of digital transformation as means of strategies could reveal critical issues industrial I4.0 systems (Ghobakhloo, 2018). This understanding could brighten why capabilities that promote economically significant gradual change are dynamic and based on strong, fast capabilities (Helfat \& Winter, 2011; Teece, Peteraf \& Leih, 2016). Ghobakhloo (2018) proposes starting with the I4.0 short-, medium- and long-term strategies as the framework indicates.

Therefore, dynamic capabilities involve facing future external and internal challenges and opportunities, deciding what the firm should be doing in the future. Those capabilities ensure firm resources access that will need and implement the appropriate organizational design (Teece, 2017) and, also, I4.0 enabling technologies could positively and significantly affect agility and competitive advantage (Teece, 2018).

An essential element is resource orchestration (Teece, 2007). This capability is based on the modularization of the platforms, which extends it to exploitation and exploration of global opportunities (Nambisan, Zahra, \& Luo, 2019). The platforms offer the integration of capabilities with existing mobile services. Hence, orchestration must ensure the smooth coordination of in-house and external physical, human and logistical elements (Teece, 2017).

Previous research paths have followed the resource-based view (RBV) and recognized several resources as the necessary preconditions for innovation and innovation capability (Ju, Zhou, Gao, \& Lu, 2013). So, innovativeness is an effective key to create value in digital transformation. At the microlevel (Figure 2), the transference of managerial best practices and overall firm-level governance (Petricevic \& Teece, 2019) is needed to debate the balance of the proposed framework.

Concerning the microfoundation level (Teece, 2007), the sensing categories are related to identification, development and assessment of new technological opportunities, and the scanning of opportunities must support effective actions among BRICS. These should include analytical systems and individual capacities to learn and to sense, filter, shape and calibrate opportunities. The microlevel considers generic contingency factors that trigger, enable and hinder the building of dynamic capabilities for digital transformation that are business model adaptation, collaboration and digital culture (Warner \& Wäger, 2019).

On the other hand, seizing is the mobilization of resources to address those needs and opportunities to capture value (Teece, 2017). Enterprise structures, procedures, designs and 
REGE 28,4

\section{6}

incentives for seizing opportunities should be addressed to promote strategic decision skills and their execution. Selecting enterprise boundaries is developed to manage complements, and "control" platforms are associated to calibrate assets and assess appropriability. It is important to understand the delineation of the customer solutions and the business models to fit the datadriven and digital decision-making process. As a result, commitment and loyalty reinforce a new digital culture and a social-economic paradigm shift in the organization at BRICS.

Finally, the digital transformation in the ability to recombine and reconfigure assets and firms' structure meanwhile firm growths and either market or technological changes. That is why continuous alignment and realignment of specific tangible and intangible assets may consider decentralization and decomposability in organizations' structures.

And, also, may consider developing integration and coordination skills; improve governance; apply "cospecialization" and manage knowledge to fit the internal and external assets combinations. Some strategic capabilities are critical to platform leaders: innovation capabilities, scanning/environmental detection capabilities and integrative features for ecosystem orchestration. Those are important at the microfoundation level (Teece, 2007). Integrative capabilities play a crucial role in enhancing platform leaders' ability to capture value (Helfat \& Raubitschek, 2018), which is another way to improve attractiveness among BRICS. Value could be enhanced by servitization and digital solutions in the ambiance of the I4.0 journey.

Moreover, the final topic sentence statement is that knowledge within this orchestration is managed differently within organizations, requiring a new and ingenious knowledge management system (Miozzo, Desyllas, Lee, \& Miles, 2016). Consequently, there is a more ingrained need for convergence and cocreation (Caputo, Garcia-Perez, Cillo, \& Giacosa, 2019), once had been discussed a strategic alliance there is another important path to organize governance and digital embeddedness toward transformation based on technology transfer and cooperation in between BRICS. Sociopolitical aspects should continue to be established in terms of economic and financial agreements toward a collaborative innovation including the countries. So that the emerging markets and the business potential could be equally preserved and perpetuated by maintaining sustainability within their industries.

\section{Methodology}

The first step of the paper was building the BRICS scenario concerning digital transformation and its relationship with the I4.0 value creation system (Zupic \& Cater, 2015). As a result, the bibliometric stage demonstrated the need to further research paths toward dynamic capability development in merging countries. After that, qualitative design research techniques were applied using content analysis (Krippendorff, 2018) at ATLAS.ti 9.0.

As a method of distinguishing secondary information data from 16 official documents of government, ministries and economic studies were analyzed by applying Atlas TI contrasting theory of 875 papers to discuss the framework. Content analysis showed research gaps, technological needs and governance to enable firms to sustain economic and innovative performance applying I4.0 value creation systems, converging an agile journey of a digital transformation.

\section{Discussion}

The emergence of multi-sided platforms is vital to comprehend better internalization theory and network effect, understanding the value creation of global organizations (Putin, 2019) as well as digital-born companies (OECD, 2019). The strategic and functional use of the I4.0 technologies could guarantee the financial gaining and sustainability based on digital resources and data-driven capability building.

Firms that have adhered to the I4.0 journey should fast develop the vital capabilities to operate efficiently improving the undergoing such transformations (Teece, Peteraf \& Leih, 2016). 
The confidence in obtaining and sustaining organizations' superior performance is provided by their digital competencies and strategic capabilities, among which analytical capabilities, transformational capabilities, integration capabilities and marketing-driven ones seem to be of fundamental importance (Batko, 2017; Kapoor \& Agarwal, 2017; Helfat \& Raubitschek, 2018; Walrave, Talmar, Podoynitsyna, Romme, \& Verbong, 2018; WEF \& Schawb, 2019).

Sensing capabilities must be driven by data and Alarchitecture on which platforms should enhance the ability to scan market opportunities (Teece, 2007). Regarding seize opportunities, there is a need to develop new smart products, digitalize processes or offer digital services. Addressing opportunities involves maintaining and improving technological competencies and, also, complementary assets. Network externalities should be an ecosystem integration benefit, and finally, decision-making processes evolved (Teece, 2017). Integrative capabilities (multi-sided/cross-side or indirect network effect) are regarding platform, ecosystem, business model design and orchestration. They are essential to creating high interdependencies among complementary asset providers and users on different sides of platform-based ecosystems (Helfat \& Raubitschek, 2018).

Also, there is a positive effect on innovation capabilities, scanning and sensing capabilities (Teece, 2017; Teece, Peteraf \& Leih, 2016). The resource integration effectiveness propitiates their incorporation, assimilation and application related to other platforms/ecosystem actors (Malerba \& Nelson, 2011, Hollebeck, 2019).

Despite China, other countries at BRICS need improvements in innovativeness, as shown in Table 1, so that trustworthiness must be guaranteed to all multinational's stakeholders. All these capabilities originated from digital architectures, aligning business and technology interests among platform stakeholders, mainly are in ECs (Teece, 2020).

Moreover, the Chinese Artificial Intelligence Development Plan aimed to connect and upgrade the entire Chinese industry by 2025 . Therefore, China has a strong and efficient start-up ecosystem with a lot of AI companies that should help firms to explore digital complementors, integrate new ecosystems and sustain strategic capabilities.

Table 1 expresses the competitiveness at BRICS highlighting education and skills capacitation for future readiness. Nevertheless, to generate and analyze data and implement the corresponding decisions, existing resources developed by the digital age should either acquire specific skills or be updated with the relevant technology components of I4.0 (Schuh, Anderl, Gausemeier, ten Hompel, \& Wahlster, 2017). In the context of MNEs 4.0, the existing knowledge could guarantee sustainable competitive advantages such as marketing reaction or different sources of knowledge (Lee, Chen \& Lu, 2009).

The content analysis of these countries' primary sanctioned documents (Table 2) does not allow the intention of how the enabling technologies, positively associated with the programs and financial subventions, could help the businesses and enterprises (Kapoor \& Agarwal, 2017). Platform's inception could provide infrastructure, information and technology which are intangible assets enabling direct transactions or value creation (Putin, 2019; Nambisan et al., 2019).

The most impacted sectors are being discussed, whereas the need to gain performance is insipidly prioritized. The knowledge-based view (KBV) (Grant, 1996) could expand understanding firms' heterogeneity and how I.40 differentiates them from competitors to sustain competitive advantage (Schwab, 2016). Due to those facts, catching up with the application of I4.0 technologies is complex and valuable, considering R\&D (Teece, 2007). The low-scored R\&D indicators suggest that incumbents at the start of a technological discontinuity at BRICS are critical. So technological platforms, which market incumbents have mastered, might be lost if the journey is not well conducted across technological discontinuities, such as the fourth industrial revolution (Sosa, 2009).

Furthermore, the KBV could be an essential determinant enhancing the understanding of firm organization and behavior, and professionals, not only in EE but also all around the 
REGE 28,4

\section{8}

world, need to cope with this movement, its availability and accessibility to data-driven technologies (Karimi \& Walter, 2015). It is considered in this aspect or mediating effect of industry-enabled technologies 4.0 and the analytical skills used (Batko, 2017).

An external component is a component of uncertainty in emerging economies, being a network of actions more relevant to be considered at BRICS as an application example. The BRICS accounted for $22 \%$ of global GDP but have received a small percentage of the global inward FDI since 2016. However, BRICS's investments are on the rise, facing a fast and radical change due to the maturation of digital technologies and their ubiquitous penetration in all markets, especially pulled by the Chinese economy.

This discussion paper explores capabilities that either mediating or moderating should strongly be provided by the digital transformation strategy, the absorption of external knowledge, involving the identification/acquisition/transformation and application of knowledge analyzed in the platforms and ecosystems. As a result, a proposition may be defined answering the question of this paper concerning whether the I4.0 technological advancement and digital transformation could be propitiated in the creation of specific capabilities, which are added as BRICS global enterprises heterogeneities. The particularities of turning either an I4.0 global organization or a digital organization operate in various environments, allowing access to the activities' digital context when applying the proposed I4.0 ECDTS framework.

Appendix 1 demonstrates the capability development research gap among the BRICS papers considering the Computer Assisted Qualitative Data Analysis (CAQDAS). There is no direct relationship among the terms according to the document sources analyzed. The programs evaluated were designed not to lose and even regain hegemony in the industrial sector and strengthen these countries' global competitiveness.

Teece (2020) recommends the country's policies and MNE strategies should be synchronized to guarantee dynamic capabilities, once, among BRICS, there is a technological pattern of catching-up countries. Moreover, due to the rapid growth of the digital economy, the importance of digital multinational enterprises (DMNEs) and technology companies (ICTMNEs) has increased, making the present theoretical study relevant to global organizations. The final sample distribution (875 papers within BRICS) shows the dissemination of publications: 443 in China, 197 in Brazil, 165 in India, 52 in Russia and 18 in South Africa. There are still gaps in exploiting technologies, and there is a partial result of the discussion of the social and economic I4.0 relevance.

Results highlight the advanced manufacturing and the use of technologies, there are a lot of effort discussing the feasibility of transforming productive environments, the gains of global and operational performance through the optimization of production processes (Ghobakhloo, 2018). However, it is considered an important gap the application of empirical studies that discuss the managerial point of view, the socioeconomic impact of this phenomenon on organizations and how ECs have demonstrated a dynamic ability to reconfigure their resources for the development of industrial capacities toward operational excellence and innovativeness.

Moreover, new business models, internal hybrid structuring and mainly the fusion of the digital and physical ambience need intelligence (Popovič, Hackney, Coelho, \& Jaklič, 2012) and data-driven decisions to orchestrate and convert effective investments (Teece, 2018). Neither technology appliance nor development sustain themselves superior performance. The policy building needs to consider uncertainty and good financial achievability; these are important at the BRICS territory and economic scenario sensibility.

The clusters in Appendix 1 highlight that there is a strong relationship between the use of technologies and assumptions of I4.0 in production systems and their contribution to the firm's performance and competitiveness. However, limitations should be considered regarding its adoption in resource restriction environments such as in developing 
countries or small and medium-sized enterprises. Furthermore, it is noteworthy to highlight that although barriers are evident the adaptation of this technological usage. Hence, there is an innovative potential to be exploited, particularly in production systems and organizations whose technology is governed in a strategic way in emerging markets where technology intensity is important to manage.

However, in Brazil, since it is relevant to the initiatives of economically important sectors, the intensity in technology and knowledge creation can be developed (Zhou \& Li, 2012), once empirical studies are frequently applied. Finally, in India, sectors worked at a strategic level looking for resources and 4.0 technology, highlighting the resource constraints environment as a relevant element. Besides, South Africa still discusses the precepts of its digitization strategy within the country, where resources may be equally scarce.

Lastly, the rapid rise of multinational technology companies represents one of the world's most notable global megacorporation trends in recent years (Gestrin \& Staudt, 2018), as could be illustrated by the frequencies and occurrences of the terms. In the boxes of Appendix 1, the grounded column indicates the number of times the code has been applied, and the column density indicates the number of connections between the tag and the theory subcategories of the data base. Each tag coded was crossed in the line by each group of official documents analyzed. As shown, Brazil and India lead research in I4.0 and digital transformation, their policies are strongly related to economic sectors. However, India is developing further research toward the strategy build through RBV lens. Even though China has the major performance in quantity of papers, the dispersion is high because defocus of its policy is broader than strategy, including economic protection and geopolitical power. Russia and South Africa indicate moderated relation with technology transfer issues and policy while analyzing strategy theories.

\section{Final considerations}

We explored the digital transformation as a post-facto contemporary phenomenon based on the view of platforms and ecosystems to create value and to obtain sustainable competitive advantages through the I4.0 ECDTS framework. We also reinforce the assumption that there are many strategic capabilities from organizations that can be complementary to enhance new ways of value creation while enrolling in the fourth industrial revolution journey.

Companies establish new forms of management to integrate and coordinate digital transformation. These new forms could address a catching-up effect of topics concerning productive efficiencies, such as technological capacity and labor force skill. Those facts determine global business firms' success or failure (Moroz, 2018; Teece, 2020).

Digitization and I4.0 technologies offer firms significant business opportunities to compete globally using digital platforms and technologies (Chen, Shaheer, Yi, \& Li, 2019). The application of big data analytics techniques (BDA) could be considered a precedent source of knowledge management, allowing companies to add value (Côrte-Real, Oliveira, \& Ruivo, 2017) mainly at the beginning of the information value chain and helping knowledge to flow achieving business excellence (Zhou \& Li, 2012).

The I4.0 policies and the reduced transaction costs propitiated by platforms and ecosystems orchestration could speed benefits of domestic firms and subsidiaries of global organizations. The BRICS present large emergent markets, with a greater diversity of participants and a higher level of resilience, furthermore behavioral profiles had been changing over the past years as well as the consumption logic and characteristics in terms of purchase conversion (OECD, 2019). From a procedural point of view, organizations need efficient processes to transform large volumes of fast and diverse data into meaningful insights (Gandomi \& Haider, 2015).

The use and importance of digital transformation elements, such as support and creation of the processes of strategic capabilities in organizations (Ghobakhloo \& Tang, 2015), allow 
REGE 28,4 critical analysis and scientific investigation. Hence, surviving companies with strong capabilities may need to shape the regulatory and governance institutions and conditions that companies themselves face (Teece, 2020). The context of digital transformation refers to the competitive advantage of agility considering the technological capacity, the operational flexibility of organizational processes and IT systems (Chen et al., 2014) as a mediating factor (Zhou \& Wu, 2010).

As a suggestion for future works, we propose to examine the exploitation of global organizations' digital knowledge-based assets with coordination of economic activities across national boundaries, assumed internally, within its hierarchical vertical structure. Empirical research could test the proposed framework, and lastly, long-term results could be monitored in domestic ones in several emerging markets industries where BRICS alliances could benefit innovation and sustainability.

\section{References}

Aarikka-Stenroos, L., \& Ritala, P. (2017). Network management in the era of ecosystems: Systematic review and management framework. Industrial Marketing Management, 67, 23-36.

Akatkin, Y.M., Karpov, O.E., Konyavskiy, V.A., \& Yasinovskaya, E.D. (2017). Digital economy: Conceptual architecture of a digital economic sector ecosystem. Business Informatics, (4), 42.

Batko, K. (2017). The relation between dynamic analytical capabilities and competitive advantage: a theoretical approach. Ekonomia I Prawo. Economics and Law, 16(3), 259-273.

Blaschke, M., Riss, U., Haki, K., \& Aier, S. (2019). Design principles for digital value co-creation networks: A service-dominant logic perspective. Electronic Markets, 29(3), 443-472. doi: 10.1007/ s12525-019-00356-9.

Caputo, F., Garcia-Perez, A., Cillo, V., \& Giacosa, E. (2019). A knowledge-based view of people and technology: Directions for a value co-creation-based learning organization. Journal of Knowledge Management, 23(7), 1314-1334.

Cenamor, J., Sjödin, D.R., \& Parida, V. (2017). Adopting a platform approach in servitization: Leveraging the value of digitalization. International Journal of Production Economics, 192, 54-65.

Chen, H., Chiang, R.H., \& Storey, V.C. (2012). Business intelligence and analytics: From big data to big impact. MIS Quarterly, 1165-1188.

Chen, Y., Wang, Y., Nevo, S., Jin, J., Wang, L., \& Chow, W.S. (2014). IT capability and organizational performance: The roles of business process agility and environmental factors. European Journal of Information Systems, 23(3), 326-342.

Chen, L., Shaheer, N., Yi, J., \& Li, S. (2019). The international penetration of international business firms: Network effects, liabilities of outsidership, and country clout. Journal of International Business Studies, 50(2), 172-192.

Côrte-Real, N., Oliveira, T., \& Ruivo, P. (2017). Assessing the business value of big data analytics in European firms. Journal of Business Research, 70, 379-390.

De Vasconcelos Gomes, L.A., Facin, A.L.F., Salerno, M.S., \& Ikenami, R.K. (2018). Unpacking the innovation ecosystem construct Evolution, gaps, and trends. Technological Forecasting and Social Change, 136, 30-48.

Eggers, J.P., \& Park, K.F. (2018). Incumbent adaptation to technological change: The past, present, and future of research on heterogeneous incumbent response. Academy of Management Annals, 12(1), 357-389.

Erro-Garcés, A. (2019). Industry 4.0: defining the research agenda. Benchmarking, ahead-ofprint(ahead-of-print). doi: 10.1108/bij-12-2018-0444.

Gandomi, A., \& Haider, M. (2015). Beyond the hype: Big data concepts, methods, and analytics. International Journal of Information Management, 35(2), 137-144. 
George, G. (2005). Slack resources and the performance of privately held firms. Academy of Management Journal, 48(4), 661-676.

George, G., \& Lin, Y. (2017). Analytics, innovation, and organizational adaptation. Innovation, 19, $16-22$.

Gestrin, M.V., \& Staudt, J. (2018). The Digital Economy, Multinational Enterprises, and International Investment Policy. Paris: OEDC. Available from: www.oeDC.org/investment/the-digitaleconomy-mnes-and-international-investment-policy.htm.

Ghobakhloo, M. (2018). The future of manufacturing industry: a strategic roadmap toward industry 4.0. Technology Management, 29(6), 910-936.

Ghobakhloo, M., \& Tang, S.H. (2015). The business value of information system-enabled ecollaboration capabilities. International Journal of e-Collaboration, 11(1), 22-56.

Grant, R.M. (1996). Prospering in dynamically competitive environments: Organizational capability as knowledge integration. Organization Science, 7(4), 375-387.

Helfat, C.E., \& Peteraf, M.A. (2009). Understanding dynamic capabilities: Progress along a developmental path. Strategic Organization, 7, 91-10.

Helfat, C.E., \& Raubitschek, R.S. (2018). Dynamic and integrative capabilities for profiting from innovation in digital platform-based ecosystems. Research Policy, 47(8), 1391-1399.

Helfat, C.E., \& Winter, S.G. (2011). Untangling dynamic and operational capabilities: a strategy for the (n)ever-changing world. Strategic Management Journal, 32, 1243-50.

Hollebeek, L.D. (2019). Developing business customer engagement through social media engagement platforms: an integrative SD logic/RBV-informed model. Industrial Marketing Management, 81, 89-98.

Jacobides, M.G., Sundararajan, A., \& Van Alstyne, M. (2019). Platforms and ecosystems: Enabling the digital economy. Briefing Paper World Economic Forum.

Ju, M., Zhou, K.Z., Gao, G.Y., \& Lu, J. (2013). Technological capability growth and performance outcome: Foreign versus local firms in China. Journal of International Marketing, 21(2), 1-16.

Kapoor, R., \& Agarwal, S. (2017). Sustaining superior performance in business ecosystems: Evidence from application software developers in the iOS and Android smartphone ecosystems. Organization Science, 28(3), 531-551.

Karimi, J., \& Walter, Z. (2015). The role of dynamic capabilities in responding to digital disruption: A factor-based study of the newspaper industry. Journal of Management Information Systems, 32(1), 39-81.

Kazan, E., Tan, C.W., Lim, E.T., Sørensen, C., \& Damsgaard, J. (2018). Disentangling digital platform competition: The case of UK mobile payment platforms. Journal of Management Information Systems, 35(1), 180-219.

Krippendorff, K. (2018). Content analysis: An introduction to its methodology. Sage Publications, Los Angeles, PA.

Lee, R.P., Chen, Q., \& Lu, X. (2009). In search of platforms to increase market responsiveness: Evidence from foreign subsidiaries. Journal of International Marketing, 17(2), 59-73.

Li-Ying, J., \& Wang, Y. (2015). Find them home or abroad? The relative contribution of international technology in-licensing to the 'indigenous innovation' in China. Long Range Planning, 48(3), 123-134.

Lima, A., \& Araújo, F.F.M. (2019). Technology environment and crowdfunding platforms in Brazil. REGE Revista De Gestão, 26(4), 352-368. doi: 10.1108/REGE-12-2018-0119.

Luo, Y., Xue, Q., \& Han, B. (2010). How emerging market governments promote outward FDI: Experience from China. Journal of world business, 45(1), 68-79.

Malerba, F., \& Nelson, R. (2011). Learning and catching up in different sectoral systems: Evidence from six industries. Industrial and Corporate Change, 20(6). 
REGE 28,4

Miozzo, M., Desyllas, P., Lee, H.F., \& Miles, I. (2016). Innovation collaboration and appropriability by knowledge-intensive business services firms. Research Policy, 45(7), 1337-1351.

Moroz, M. (2018). Acceleration of digital transformation as a result of launching programs financed from public funds: Assessment of the implementation of the operational program digital Poland. Foundations of Management, 10(1), 59-74.

Nambisan, S., Zahra, S.A., \& Luo, Y. (2019). Global platforms and ecosystems: Implications for international business theories. Journal of International Business Studies, 50(9), 1464-1486.

OECD (2019). Vectors of digital transformation. The OECD Digital Economy Papers, Available from: https://www.oecd-ilibrary.org/science-and-technology/vectors-of-digitaltransformation_ 5ade2bba-en.

Petricevic, O., \& Teece, D.J. (2019). The structural reshaping of globalization: Implications for strategic sectors, profiting from innovation, and the multinational enterprise. Journal of International Business Studies, 50(9), 1487-1512.

Popovič, A., Hackney, R., Coelho, P.S., \& Jaklič, J. (2012). Towards business intelligence systems success: Effects of maturity and culture on analytical decision making. Decision Support Systems, 54(1), 729-739.

Putin, V. (2019). ASI's Expert Council Ordinance (in Russian) [July 27, 2011]. Available from: https:// asi.ru/eng/agency/supervisory_expert_board/\# (accessed 17 April 2019).

Schallmo, D., Williams, C. A., \& Boardman, L. (2017). Digital transformation of business models best practices, enablers, and roadmap. International Journal of Innovation Management, 21(08), 1740014.

Schuh, G., Anderl, R., Gausemeier, J., ten Hompel, M., \& Wahlster, W. (Eds.), (2017). Industrie 4.0 Maturity Index. Managing the Digital Transformation of Companies (acatech STUDY). Munich: Herbert Utz Verlag.

Schwab, K. (2016). The fourth industrial revolution. Geneva: World Economic Forum.

Sheng, S., Zhou, K.Z., \& Li, J.J. (2011). The effects of business and political ties on firm performance: Evidence from China. Journal of Marketing, 75(1), 1-15.

Silva, I.S., Bernardes, P., Ramalho, F.D., Ekel, P.I., Martins, C.A.P.S., \& Libório, M.P. (2019). Continuous results-driven innovation management program. REGE Revista De Gestão, 26(4), 389-408. doi: 10.1108/REGE-01-2019-0006.

Sosa, M.L. (2009). Application-specific R\&D capabilities and the advantage of incumbents: Evidence from the anticancer drug market. Management Science, 55(8), 1409-1422.

Subramaniam, M., Iyer, B., \& Venkatraman, V. (2019). Competing in digital ecosystems. Business Horizons, 62(1), 83-94. doi: 10.1016/j.bushor.2018.08.013.

Teece, D.J. (2007). Explicating dynamic capabilities: The nature and micro-foundations of (sustainable) enterprise performance. Strategic Management Journal, 28, 1319-1350.

Teece, D.J. (2009). Dynamic capabilities and strategic management. Oxford: Oxford University Press.

Teece, D.J. (2017). Dynamic capabilities and (digital) platform lifecycles. Entrepreneurship, Innovation, and Platforms: Emerald Publishing, 211-225.

Teece, D.J. (2018). Profiting from innovation in the digital economy: Enabling technologies, standards, and licensing models in the wireless world. Res. Policy, 1.

Teece, D.J. (2020). Fundamental issues in strategy: Time to reassess?. Strategy. Manag. Rev., 1(1).

Teece, D.J., Peteraf, M., \& Leih, S. (2016). Dynamic capabilities and organizational agility: Risk, uncertainty, and strategy in the innovation economy. California Management Review, 58(4), 13-35.

Vanacker, T., Collewaert, V., \& Zahra, S.A. (2017). Slack resources, firm performance, and the institutional context: Evidence from privately held European firms. Strategic Management Journal, 38(6), 1305-1326. 
Veretekhina, S.V., Karyagina, T.V., Potekhina, E.V., Nakhratova, E.E., Pronkina, T.V., \& Makushkin, S.A. (2018). Mathematical methods of an estimation of economic efficiency of investments and the sequence of execution of stages of investment on the example of the national technology initiative of the Russian Federation. 75. Available from: www.mjltm.com; info@mjltm.org.

Walrave, B., Talmar, M., Podoynitsyna, K.S., Romme, A.G.L., \& Verbong, G.P. (2018). A multi-level perspective on innovation ecosystems for path-breaking innovation. Technological Forecasting and Social Change, 136, 103-113.

Warner, K.S., \& Wäger, M. (2019). Building dynamic capabilities for digital transformation: An ongoing process of strategic renewal. Long Range Planning, 52(3), 326-349.

World Economic Forum, Schawb, K. (2019). The global competitiveness report. Geneva: World Economic Forum.

Zhang, J., Wu, W.P., \& Chen, R. (2018). Leveraging channel management capability for knowledge transfer in international joint ventures in an emerging market: A moderated mediation model. Industrial Marketing Management, 75, 173-183.

Zhou, K.Z., \& Li, C.B. (2012). How knowledge affects radical innovation: Knowledge base, market knowledge acquisition, and internal knowledge sharing. Strategic Management Journal, 33(9), 1090-1102.

Zhou, K.Z., \& Wu, F. (2010). Technological capability, strategic flexibility, and product innovation. Strategic Management Journal, 31(5), 547-561.

Zupic, I., \& Čater, T. (2015). Bibliometric methods in management and organization. Organizational Research Methods, 18(3), 429.

\section{The context of} BRICS 
REGE

28,4

314

\section{Appendix 1}



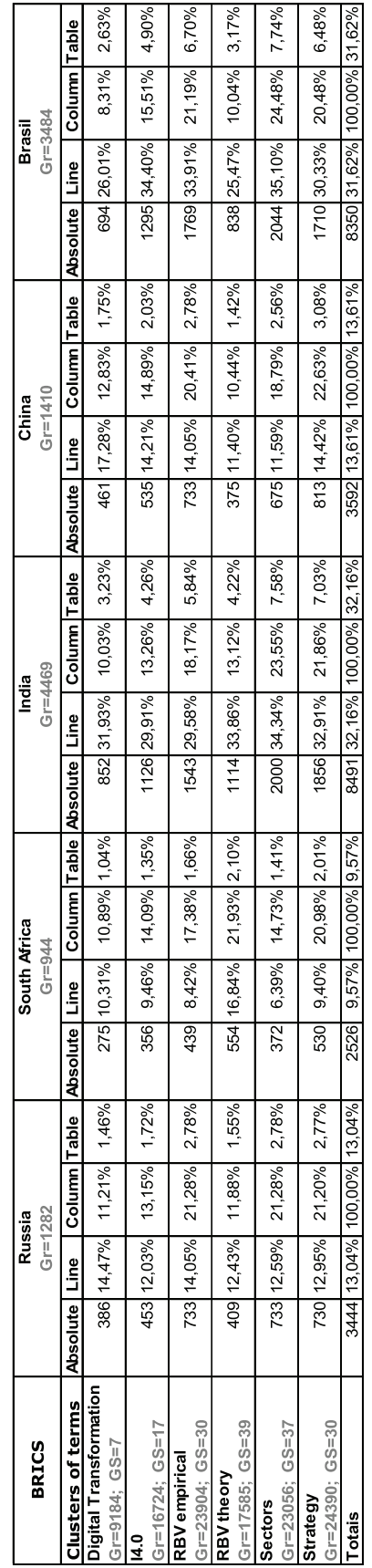




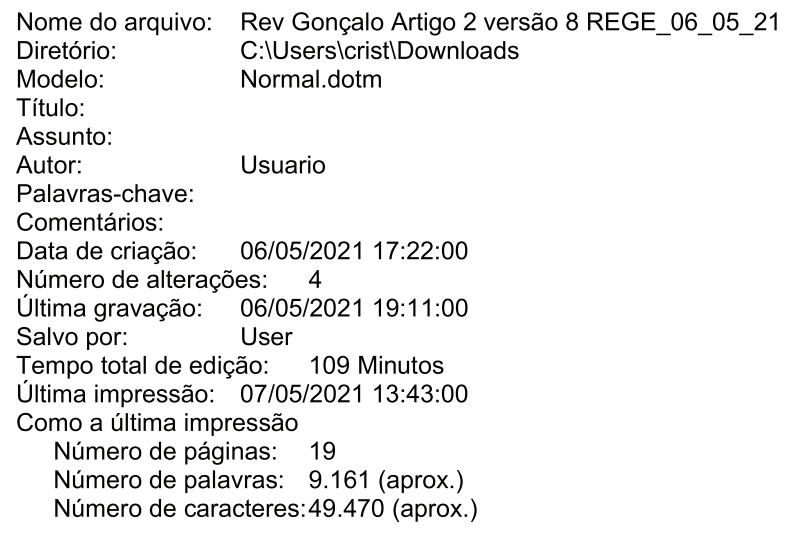
Normal.dotm

Usuario

Palavras-chave:

Comentários:

Data de criação: $\quad$ 06/05/2021 17:22:00

Número de alterações: 4

Última gravação: $\quad$ 06/05/2021 19:11:00

Salvo por: User

Tempo total de edição: 109 Minutos

Última impressão: 07/05/2021 13:43:00

Como a última impressão

Número de páginas: 19

Número de palavras: 9.161 (aprox.)

Número de caracteres:49.470 (aprox.)

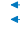

The context of BRICS

\section{Corresponding author}

Cristiana Rennó D’Oliveira Andrade can be contacted at: cristianarennodoliveiraandrade@gmail.com

For instructions on how to order reprints of this article, please visit our website:

www.emeraldgrouppublishing.com/licensing/reprints.htm

Or contact us for further details: permissions@emeraldinsight.com 